\title{
Cadmium Accumulation Risk in Vegetables and Rice in Southern China: Insights from Solid-Solution Partitioning and Plant Uptake Factor
}

\author{
Yang Yang, ${ }^{\dagger, \ddagger}$ Meie Wang, ${ }^{\dagger}$ Weiping Chen, ${ }^{*}$, Yanling Li, $^{\dagger, \dagger}$ and Chi Peng ${ }^{\dagger}$ \\ ${ }^{\dagger}$ State Key Laboratory of Urban and Regional Ecology, Research Center for Eco-environmental Sciences, Chinese Academy of \\ Sciences, Beijing 100085, China \\ ${ }^{\ddagger}$ University of Chinese Academy of Sciences, Beijing 100049, China
}

\section{Supporting Information}

\begin{abstract}
Solid-solution partitioning coefficient $\left(K_{\mathrm{d}}\right)$ and plant uptake factor (PUF) largely determine the solubility and mobility of soil Cd to food crops. A four-year regional investigation was conducted in contaminated vegetable and paddy fields of southern China to quantify the variability in $K_{\mathrm{d}}$ and PUF. The distributions of $K_{\mathrm{d}}$ and PUF characterizing transfers of Cd from soil to vegetable and rice are probabilistic in nature. Dynamics in soil $\mathrm{pH}$ and soil $\mathrm{Zn}$ greatly affected the variations of $K_{\mathrm{d}}$. In addition to soil $\mathrm{pH}$, soil organic matter had a major influence on PUF variations in vegetables. Heavy leaching of soil Mn caused a higher $\mathrm{Cd}$ accumulation in rice grain. Dietary ingestion of $85.5 \%$ of the locally produced vegetable and rice would have adverse health risks, with rice consumption contributing $97.2 \%$ of the risk. A probabilistic risk analysis based on derived transfer function reveals the amorphous $\mathrm{Mn}$ oxide content exerts a major influence on $\mathrm{Cd}$ accumulation in rice in $\mathrm{pH}$ conditions below 5.5. Risk estimation and field experiments show that to limit the $\mathrm{Cd}$ concentration in rice grains, soil management strategies should include improving the $\mathrm{pH}$ and soil $\mathrm{Mn}$ concentration to around 6.0 and $345 \mathrm{mg} \mathrm{kg}^{-1}$, respectively. Our work illustrates that reestablishing a balance in trace elements in soils' labile pool provides an effective risk-based approach for safer crop practices.
\end{abstract}

KEYWORDS: solid-solution partitioning, plant uptake, rice, vegetable, cadmium

\section{INTRODUCTION}

Cadmium (Cd) is one of the most harmful and widespread contaminants in agricultural soil. ${ }^{1,2} \mathrm{Cd}$ is readily taken up by crop plants and threatens human health through the food chain. ${ }^{3}$ Dietary food intake accounts for approximately $90 \%$ of the total $\mathrm{Cd}$ exposure, ${ }^{2}$ and vegetables and rice are the biggest contributors to $\mathrm{Cd}$ exposure in the general nonsmoking population. $^{4-6}$ Long-term consumption of Cd-contaminated vegetables and rice is associated with osteoporosis, kidney disease, and cardiovascular disease. ${ }^{7,8}$ China produces and consumes more vegetables and rice than any other country in the world. ${ }^{9,10}$ About 13 million hectares of the cultivated land of China is reported to be contaminated by Cd. ${ }^{11}$ Therefore, an important and urgent task in China is to control the risks associated with $\mathrm{Cd}$ in crop plants.

Vegetable and rice plants take up Cd from its labile pool in soils. $^{2,13}$ Solid-solution partitioning and plant uptake are important processes determining metal bioavailabilty, phytoavailability, and ecotoxicity. ${ }^{14-16}$ The solid-solution partitioning coefficient $\left(K_{\mathrm{d}}\right)$ is often used to estimate metal ion concentration or activity in soil and predict metal mobility as well as potential leaching losses. ${ }^{17,18}$ The potential transfer of trace metals from soil to plants is usually estimated by the dimensionless plant uptake factor (PUF) defined as the ratio of metal concentration in edible plant tissues to that in soil. ${ }^{19}$ Both $K_{\mathrm{d}}$ and PUF help normalize the differences caused by mineralogical and soil conditions, and thus standardize the risk assessment of trace metals in soil-crop systems. ${ }^{20,21} K_{\mathrm{d}}$ and PUF are introduced in many studies to predict the potential risk of toxic metals in cropland soil, ${ }^{22}$ inform soil protection guideline, ${ }^{23}$ and assess the $\mathrm{Cd}$ intake risk. ${ }^{24}$ Simple generic values of $K_{\mathrm{d}}$ and PUF are widely used in risk assessment models such as the Contaminated Land Exposure Assessment Model in the U.K., ${ }^{25}$ the Csoil Model in The Netherlands, ${ }^{26}$ and the Cadmium Accumulation Model in China. ${ }^{27}$ However, these two parameters are not constants but vary widely with different environmental factors. ${ }^{14,19}$ Significant variables contributing to the variability of $K_{\mathrm{d}}$ and PUF are soil $\mathrm{pH}$, soil organic matter, cation exchange capacity, texture, $\mathrm{Fe} / \mathrm{Mn}$ oxides, and crop plant species. ${ }^{5,28}$

Predictive $K_{\mathrm{d}}$ and PUF models factoring in soil $\mathrm{pH}$ have been developed in recent years. ${ }^{16,23}$ The limitation of these studies is that the transfer functions are not universal and cannot be generally used to accurately assess potential risk of $\mathrm{Cd}$ in agricultural systems. Lim et al., ${ }^{18}$ Sauvé et al., ${ }^{28}$ and Groenenberg et al. ${ }^{29}$ compared their derived models with experimental results and indicated that literature-derived functions underestimate the site-specific environmental factors. The processes of soil $\mathrm{Cd}$ accumulation and crop uptake are dynamic and complex, ${ }^{12,30}$ but $K_{\mathrm{d}}$ and PUF are seldom parametrized accordingly. In addition, most studies were conducted over only one year and were carried out on spike metals or potted experiments having a narrow range of soil

Received: April 26, 2017

Revised: June 9, 2017

Accepted: June 14, 2017

Published: June 21, 2017 

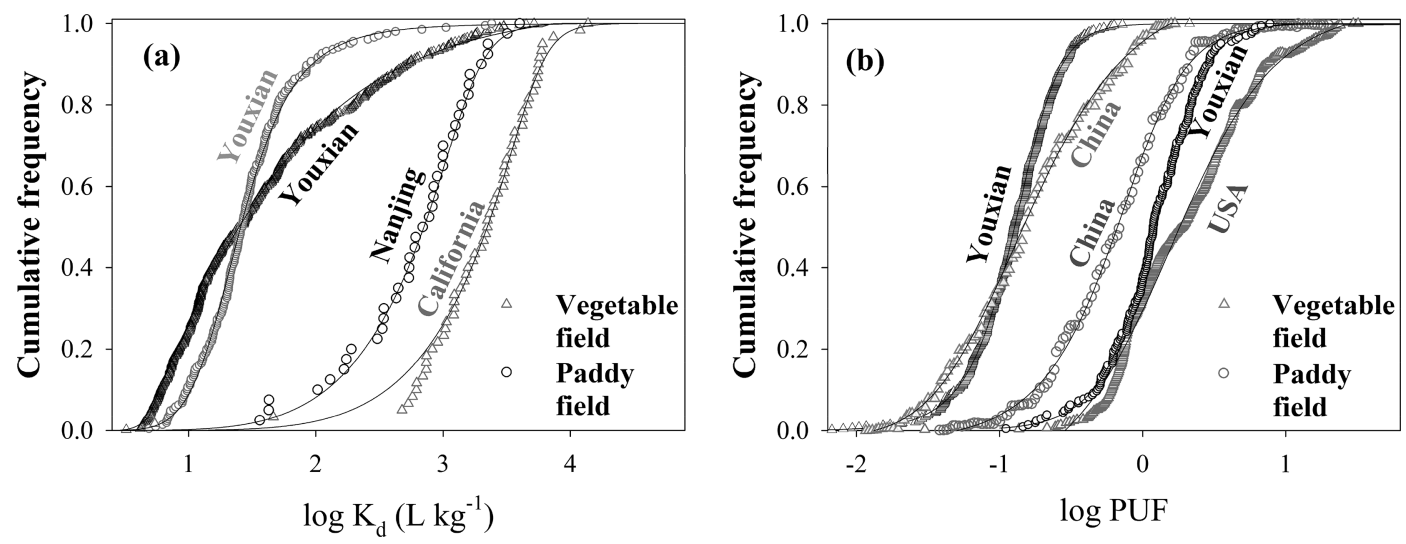

Figure 1. Probability distribution of (a): $K_{\mathrm{d}}$ in vegetable and paddy fields; and (b) the PUF of vegetable and rice from the study area and other studies. $K_{\mathrm{d}}$ and PUF data are fitted by a log-normal distribution function. The $K_{\mathrm{d}}$ data in Nanjing and California from Chen et al. ${ }^{21}$ and Luo et al. ${ }^{22}$ The PUF data in China and U.S.A. from Chen et al. ${ }^{21}$ and Zhang et al. ${ }^{36}$

compositions. ${ }^{17,23}$ The limited field data restrict the use of these $K_{d}$ and PUF models in risk assessments. ${ }^{25}$ Many national environmental agencies recommend developing systematic methods to characterize $K_{d}$ and PUF to determine site-specific risk and ultimately human exposure, ${ }^{21,22,24}$ but such detailed comprehensive studies are limited.

The prefecture of Youxian is a major regional crop producer in southern China (Figure S1 in the Supporting Information) and is known nationwide as a "Cd-tainted rice" region. ${ }^{13} \mathrm{On}$ the basis of a four-year regional investigation and field trial in vegetable and paddy fields of this area, we aimed (1) to characterize $K_{\mathrm{d}}$ and PUF in probabilistic terms; (2) to identify the major factors influencing $K_{\mathrm{d}}$ and PUF; and (3) to provide recommendations toward a more risk-based perspective for the safer production of vegetables and rice.

\section{MATERIALS AND METHODS}

Survey and Sampling. A total of 683 paired soil-crop sites were selected throughout the Youxian prefecture $\left(113.32^{\circ} \mathrm{E}\right.$ long., $27.01^{\circ} \mathrm{N}$ lat.), including 478 vegetable field sites and 205 paddy field sites. At each site, the types of crop cultivars and growth conditions were investigated and recorded. Five major consumed leafy-type vegetables in the study area were collected, comprising bokchoy (Brassica rape var. chinensis), Chinese cabbage (Brassica pekinensis. L.), mustard (Brassica juncea. L.), lettuce (Lactuca sativa. L.), and red cabbage (Brassica campestris subsp. chinensis var. purpuria). Rice samples belonged to the late indica cultivars. Topsoil samples $(0-20 \mathrm{~cm})$ were collected from the site of each crop plant harvest. Detailed information on samplings is available in Table S1 in the Supporting Information (SI).

The amount of crop residue returning to the soil was measured in the fields following each year's harvest using the methods described in Wang et al. ${ }^{31}$ Meteorological data and agronomic information including farmland cultivation, management, irrigation, fertilization and the main agricultural inputs and outputs were recorded and are listed in Tables S2 and S3. The consumption ratios of the vegetables $\left(46.4 \pm 23.6 \mathrm{~g} \mathrm{DW} \mathrm{d}^{-1}\right)$ and rice $\left(258 \pm 78.7 \mathrm{~g} \mathrm{DW} \mathrm{d}^{-1}\right)$ in the study area were obtained using a standardized questionnaire survey $(n=671$, Table S4) throughout the study area. The body weights of adults (58 $\pm 9.1 \mathrm{~kg}$ capita) were obtained from a health survey $(n=3442)$ conducted by the Youxian health agency (Table S4).

Chemical Analyses. Samples of soil, vegetable, and rice were prepared according to the procedure described in Wang et al. ${ }^{13}$ and Yang et al. ${ }^{32}$ The bulk density of soil was measured with the core cutter method. ${ }^{31}$ The soil $\mathrm{pH}$ and electrical conductivity were measured in 1:2.5 and 1:5 (w/v) soil and water suspension, respectively. The contents of soil organic matter $\left(\mathrm{K}_{2} \mathrm{Cr}_{2} \mathrm{O}_{7}-\mathrm{H}_{2} \mathrm{SO}_{4}\right.$, oil-bath-heating), clay (hydrometer method), cation exchange capacity (1 mol NH${ }_{4} \mathrm{OAc}$ buffered at $\mathrm{pH} 7.0$ ), total $\mathrm{C}$ and $\mathrm{N}$ (dry combustion method), amorphous $\mathrm{Fe}$, and $\mathrm{Mn}$ oxide $\left(\left(\mathrm{NH}_{4}\right)_{2} \mathrm{C}_{2} \mathrm{O}_{4}-\mathrm{H}_{2} \mathrm{C}_{2} \mathrm{O}_{4}\right.$ extraction) were analyzed according to routine analytical methods of agricultural chemistry in soil. ${ }^{33}$ The solubility and speciation of $\mathrm{Cd}$ were determined using 1:2(w/v) soil extracts with $10 \mathrm{M} \mathrm{KNO}_{3}$ to eliminate the influences of other salts on the total ionic strength of the solution. ${ }^{28}$ The detailed procedure is described in Luo et al. ${ }^{22}$

The crop samples were digested with concentrated $\mathrm{HNO}_{3}-\mathrm{HClO}_{4}$, whereas soil was digested with a mixture of $\mathrm{HCl}-\mathrm{HNO}_{3}-\mathrm{HF}-\mathrm{HClO}_{4}$ solution. ${ }^{13,33}$ Concentrations of $\mathrm{Cd}$ and $\mathrm{Zn}$ were determined by GFAAS (ZEEnit700, Analytik Jena, Germany). ${ }^{34}$ Concentration of Fe and $\mathrm{Mn}$ were determined by ICP-OES (DV4300, PerkinElmer, Norwalk, U.S.A.). ${ }^{34}$ Basic information on determined physicochemical properties in the vegetable and paddy fields included in this study is available in the Table S5.

Quality Assurance. Sample blanks and standard reference materials (GBW10014 for vegetables, GBW10045 for Hunan rice, and GBW07405 for soils) were included in every batch of the analyses. ${ }^{35}$ The recovery ratios of standards for $\mathrm{Cd}$ and $\mathrm{Zn}$ ranged from $82.4 \%$ to $118 \%$ and $79.5 \%$ to $119 \%$ for GBW10014, $93.1 \%$ to $108 \%$ and $83.8 \%$ to $121 \%$ for GBW10045, and $92.1 \%$ to $110 \%$, and $83.7 \%$ to $118 \%$ for GBW07405, respectively.

Statistical Analyses. One way analysis of variance (ANOVA) was conducted to evaluate the differences in vegetable and paddy fields, in which significant effects were compared using the Turkey's test $(p<$ 0.05 ). Spearman correlation analysis (two-tailed) and stepwise multiple linear regression analysis were conducted using the Genstat 17.0. The uncertainty in the risk assessments was estimated using the Monte Carlo simulation method, obtained following 10000 iterations using the Matlab 14.0a.

\section{RESULTS AND DISCUSSION}

Characterization of $K_{\mathrm{d}}$ and PUF. As shown in Figure 1, $K_{\mathrm{d}}$ values ranged from 3.24 to $5,145 \mathrm{~L} \mathrm{~kg}^{-1}$, with a geometric mean value of $35.5 \mathrm{~L} \mathrm{~kg}^{-1}$. The range of $K_{\mathrm{d}}$ values was within the range reported by Sauvé et al. ${ }^{28}\left(0.44-192000 \mathrm{~L} \mathrm{~kg}^{-1}\right)$, but comparatively narrower. $K_{\mathrm{d}}$ values in paddy fields (geometric mean $K_{\mathrm{d}}=29.5 \mathrm{~L} \mathrm{~kg}^{-1}$ ) were significantly lower than that in vegetables fields (geometric mean $K_{\mathrm{d}}=38.4 \mathrm{~L} \mathrm{~kg}^{-1}$ ), suggesting that $\mathrm{Cd}$ in solution phase is proportionately higher in paddy soils, thus increasing the accumulation risk for rice crops. The PUF value averaged 1.52 for rice fields, nearly 10 times that of vegetable fields (0.15) (Table S5). About $0.2 \%$ and $62 \%$ of vegetable and rice fields had PUF values above 1 . These results demonstrate that $\mathrm{Cd}$ is effectively transferred from soil to rice grains. 

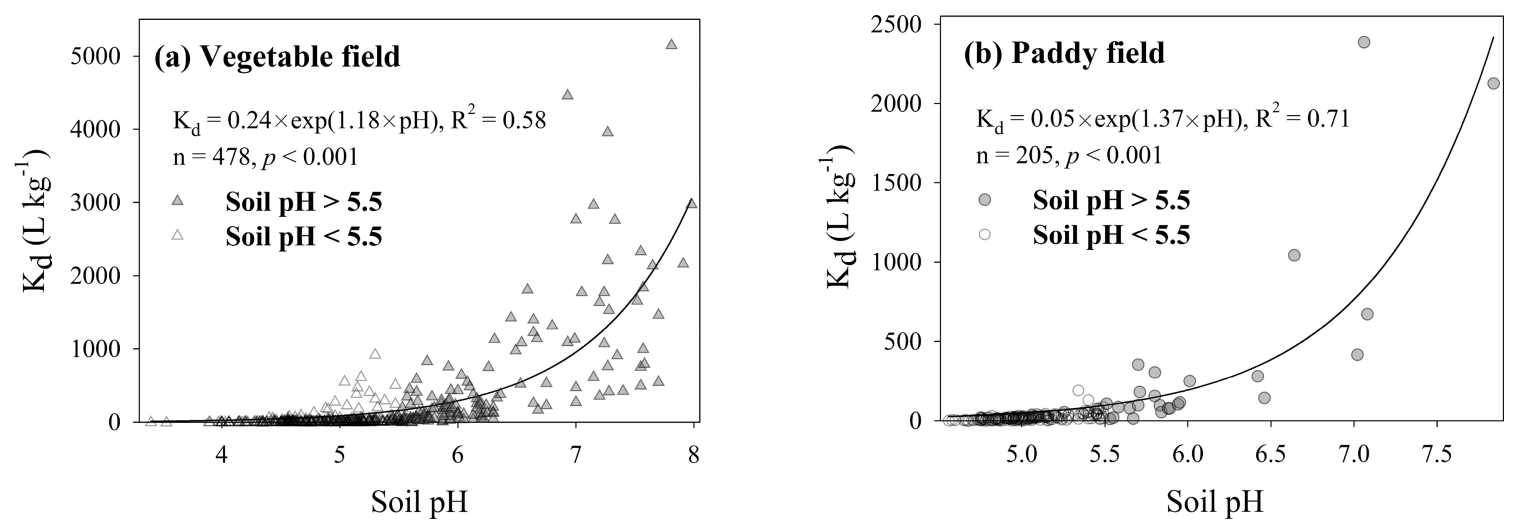

Figure 2. Relationship between soil $\mathrm{pH}$ and $K_{\mathrm{d}}$ in (a) vegetable and (b) paddy field.

Table 1. Derived Transfer Functions for $K_{d}$ and PUF in Vegetable and Paddy Field

\begin{tabular}{|c|c|c|c|c|c|c|}
\hline \multirow[b]{2}{*}{ no. of equations } & \multirow[b]{2}{*}{ field } & \multirow[b]{2}{*}{ regression model } & \multicolumn{4}{|c|}{ model validation } \\
\hline & & & $n$ & $\mathrm{R}^{2}$ & RMSE & $p$ \\
\hline 1 & vegetable & $\log \left[K_{\mathrm{d}}\right]=-3.17+0.74 \mathrm{pH}+0.27 \log [\mathrm{Zn}]+0.29 \log [\mathrm{SOM}]$ & 478 & 0.69 & 0.41 & $<0.001$ \\
\hline 2 & rice & $\log \left[K_{\mathrm{d}}\right]=-5.41+0.83 \mathrm{pH}+1.3 \log [\mathrm{Zn}]$ & 205 & 0.81 & 0.19 & $<0.001$ \\
\hline 3 & vegetable & $\log [\mathrm{PUF}]=1.08-0.25 \mathrm{pH}-0.54 \log [\mathrm{SOM}]$ & 478 & 0.62 & 0.19 & $<0.001$ \\
\hline 4 & rice & $\log [\mathrm{PUF}]=2.04-0.23 \mathrm{pH}-0.43 \log \left[\mathrm{Mn}_{\mathrm{ox}}\right]$ & 205 & 0.37 & 0.26 & $<0.001$ \\
\hline 5 & rice & $\log \left[\mathrm{Cd}_{\text {rice }}\right]=1.62-0.22 \mathrm{pH}+0.26 \log \left[\mathrm{Cd}_{\text {soil }}\right]-0.41 \log \left[\mathrm{Mn}_{\text {ox }}\right]$ & 205 & 0.42 & 0.23 & $<0.001$ \\
\hline
\end{tabular}

Figure 1 also illustrates that the distribution of $K_{d}$ and PUF in the Youxian prefecture and data from other studies are better matched by a probabilistic distribution function. ${ }^{21,36} K_{d}$ values range approximately over 3 orders of magnitude, and are lower than reported $K_{d}$ values in Nanjing and California (Figure 1a), suggesting that fields in the studied region have generally poor $\mathrm{Cd}$ retention capacity. These results further illustrate the seriousness of the $\mathrm{Cd}$ contamination situation in the cropland soils of the Youxian prefecture.

The PUF values showed a 41-fold and 70-fold variation in vegetable and rice fields (Figure $1 \mathrm{~b}$ ), respectively. In comparison with the PUF values throughout the cropland soils of China and California, the PUF of rice fields in our study is much higher, while PUF of vegetable fields in this region is much smaller, suggesting a potential risk for rice cultivation in the study area. Correlation analyses showed a weak relationship between total $\mathrm{Cd}$ in soils and crop plants. Among uncontaminated soil (soil Cd $<0.3 \mathrm{mg} \mathrm{kg}^{-1}$ ), ${ }^{37} 67.1 \%$ (102 of 152) of vegetable fields had low levels of PUF (lower than their averaged value, 0.15 ), and $62.2 \%$ (46 of 74) of paddy fields had low levels of PUF (lower than their averaged value, 1.52). These results indicate that soil $\mathrm{Cd}$ alone is generally a poor predictor for $\mathrm{Cd}$ accumulation in crop plants.

In general, the great site-to-site variations of $K_{\mathrm{d}}$ and PUF indicate a complicated relationship between $\mathrm{Cd}$ concentration in soil, soil solution, and crop plants and environmental factors, thus making risk assessment and management more challenging. Although the use of representative $K_{d}$ and PUF values in relevant works may be similar, ${ }^{24,26,28}$ the probability risk interpretations are quite different. Results indicate that characterizing $K_{\mathrm{d}}$ and PUF in probabilistic terms is necessary for a consistent risk assessment.

Relationships Between $K_{\mathrm{d}}$ and Soil Factors. The bioavailability of $\mathrm{Cd}$ in agricultural soil is governed by a range of soil factors. ${ }^{6,12}$ Values of $K_{\mathrm{d}}$ showed a curvilinear increase with $\mathrm{pH}$ over the range 3.4-7.84 (Figure 2). Soil $\mathrm{pH}$ alone accounted for $58 \%$ and $71 \%$ of the variability in vegetable fields and paddy fields, respectively, suggesting that $\mathrm{Cd}$ in paddy fields is more sensitive to the influence of soil $\mathrm{pH}$ than in vegetable fields.

A pH value of 5.5 is the acidification threshold of soils in southern China. ${ }^{37}$ The $K_{\mathrm{d}}$ values in both vegetable and paddy soils are divided into two groups depending on this $\mathrm{pH}$ threshold, as shown in Figure 2. In the acidic soil group $(\mathrm{pH}<$ 5.5 ), 56.1\% (268 of 478) of vegetable fields had low levels of $K_{d}$ (lower than their geometric mean, $38.4 \mathrm{~L} \mathrm{~kg}^{-1}$ ), and $56.1 \%$ of paddy fields (115 of 205) had low levels of $K_{d}$ (lower than their geometric mean, $29.5 \mathrm{~L} \mathrm{~kg}^{-1}$ ). Soil acidification increases deprotonation of the soil surface and therefore reduces the adsorption capacity and the holding capacity of $\mathrm{Cd}$ in agricultural soils. ${ }^{9,17}$ Soil $\mathrm{pH}$ in sampled soils averaged 5.3, and $74.4 \%$ of fields (508 of 683 ) belonged to the acidic soil group $(\mathrm{pH}<5.5)$. The strong acidification of soils in study area implies a lower retention capacity of cationic $\mathrm{Cd}$ and thus uptake by crop plants.

Stepwise multiple linear regression was used to describe the relationship between analyzed factors based on the extended Freundlich-type function, ${ }^{29}$ as shown in Table 1 . In addition to the $\mathrm{pH}$, soil $\mathrm{Zn}$ greatly affected the variations of $K_{\mathrm{d}}$ in both soil types (eqs 1 and 2, Table 1), since $\mathrm{Zn}$ and $\mathrm{Cd}$ in the available metal pool have similar affinity for sorption sites. ${ }^{15,29}$ Soil organic matter (SOM) readily binds $\mathrm{Cd}$ cations and can form strong complexes with them and thus reduces the bioavailability of the metal, ${ }^{16}$ and this effect was significant in vegetable soils (eq 1, Table 1). In both soil types, cation-exchange capacity (CEC), clay, amorphous $\mathrm{Fe}$ oxide $\left(\mathrm{Fe}_{\mathrm{ox}}\right)$, and amorphous $\mathrm{Mn}$ oxide $\left(\mathrm{Mn}_{\mathrm{ox}}\right)$, and nitrogenous fertilizer input showed a correlation with $\mathrm{pH}, \mathrm{SOM}$ and $\mathrm{Zn}\left(r=0.106^{*}-0.395^{* *}\right)$, suggesting that these factors may influence $\mathrm{Cd}$ bioavailability indirectly.

In the study area, paddy fields were ploughed deeply once or twice annually, whereas vegetable soils were ploughed more frequently (the mode of cultivation varied between 3 deep ploughings and 15 shallow ploughings) (Table S3). Frequent 

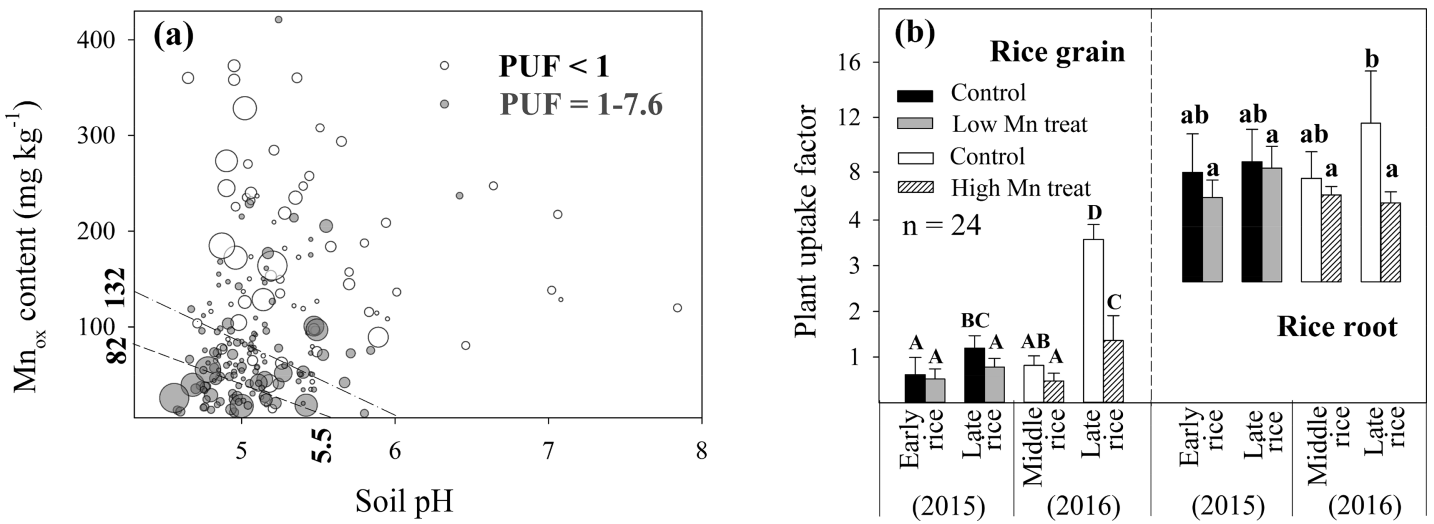

Figure 3. Influence of (a) soil $\mathrm{pH}$ and $\mathrm{Mn}_{\mathrm{ox}}$ on rice PUF (the bigger the circle, the larger the PUF value); (b) Mn fertilizer ( $\mathrm{MnSO}_{4}$ ) on the PUF of rice grain and rice root (the low and high $\mathrm{Mn}$ treat represent the rates of 75 and $375 \mathrm{~kg} \mathrm{ha}^{-1}$, respectively; the low Mn treat increased the soil Mn content from 268 to $294 \mathrm{mg} \mathrm{kg}^{-1}$ and from 250 to $284 \mathrm{mg} \mathrm{kg}^{-1}$ for early rice and late rice crops in 2015, and the high Mn treat increased the soil Mn content from 254 to $365 \mathrm{mg} \mathrm{kg}^{-1}$ and from 252 to $595 \mathrm{mg} \mathrm{kg}^{-1}$ for middle rice and late rice crops in 2016, respectively; bars with different letters indicate significant differences $(p<0.05)$ between Mn treatments).

ploughings cause a strong disturbance of the surface soil profile $(0-20 \mathrm{~cm})$, destroy soil aggregates, improve the soil aeration porosity, and speed up the decomposition and mineralization of SOM. ${ }^{10,31}$ Fields ploughed three times a year or more for vegetable production required more fertilizer input. The application of nitrogenous fertilizer in the vegetable and paddy fields in this study reached 332 and $140 \mathrm{~kg} \mathrm{ha}^{-1}$, respectively, significantly higher than applications of phosphorus and potassium fertilizer (Table S3). The negative correlation between nitrogenous fertilizer input and soil $\mathrm{pH}$ $\left(r=-0.366^{*}\right)$ and SOM $\left(r=-0.219^{*}\right)$ in vegetable fields shows that excessive fertilizer application may lead to soil acidification and a decline in SOM owing to nitrification and physiological acidity. ${ }^{9,11}$ In addition, vegetable field practices led to drought conditions during the whole tillage stage, while paddy fields alternated between dry and wet conditions. Aerobic and warmer conditions further led to decreases in $\mathrm{Fe}_{\mathrm{ox}}$ and $\mathrm{Mn}_{\mathrm{ox}}$ in vegetable fields (Table S5). Accordingly, the decreases of $\mathrm{SOM}, \mathrm{CEC}, \mathrm{Fe}_{\mathrm{ox}}$ and $\mathrm{Mn}_{\mathrm{ox}}$ resulted in a higher solubility of $\mathrm{Cd}^{2+}$ in vegetable fields compared to paddy fields. Other studies in Hunan, ${ }^{10}$ Guangdong, ${ }^{31}$ and Jiangsu ${ }^{38}$ found similar decreased soil fertility conditions in vegetable fields compared with paddy fields.

Relationships Between PUF and Soil Factors. The derived transfer functions revealed that in addition to soil $\mathrm{pH}$, SOM had a major influence on PUF variation in vegetable fields, and $\mathrm{Mn}_{\mathrm{ox}}$ is the principal control factor of PUF in rice field (eqs 3 and 4, Table 1$)$. In the acidic soil group $(\mathrm{pH}<5.5)$, the PUF averaged 0.2 and 1.6 for vegetable and rice fields, respectively, and was significantly higher than the PUF in fields with $\mathrm{pH}$ values above 5.5. In particular, the low $K_{\mathrm{d}}$ values (lower than their geometric mean value) were mainly located in sites with soil $\mathrm{pH}<5.5$ (Figure 2). These results suggest that soil acidification increased the $\mathrm{Cd}$ availability and thus uptake by crop plants.

SOM was closely correlated with PUF in vegetable fields $(r=$ $-0.362^{* *}$ ) (Table S6). When the SOM content was below 10 $\mathrm{g} \mathrm{kg}^{-1}, 63 \%$ of the vegetable fields had a PUF greater than their mean value $(0.15)$. This ratio significantly decreased to $17.2 \%$ when SOM content in vegetable soil increased to $30 \mathrm{~g} \mathrm{~kg}^{-1}$. The relationship between SOM and rice PUF is relatively poor $(r=0.053)$. The root biomass and plant residue amount of vegetables was only $33.7 \%$ of that in rice, which resulted in a significantly lower $\mathrm{C} / \mathrm{N}$ ratio in vegetable fields (10.4) compared to paddy fields (12.4) (Table S5). Low $\mathrm{C} / \mathrm{N}$ in vegetable fields shows an inhibitory effect on microorganism activity, and decreases microbial biomass and metabolites. ${ }^{38}$ This could partially explain the lower SOM in vegetable fields $\left(20 \mathrm{~g} \mathrm{~kg}^{-1}\right)$ compared to paddy fields $\left(39.6 \mathrm{~g} \mathrm{~kg}^{-1}\right)$ (Table S5), and the significant influence of SOM on Cd accumulation in vegetables.

A Mn transporter (OsNRAMP5) has recently been proposed as the major Cd uptake pathway in rice. ${ }^{7,30}$ As shown in Figure 3a, PUF values of paddy soils are separated clearly into two groups by the $\mathrm{Mn}_{\mathrm{ox}}$ content of $82 \mathrm{mg} \mathrm{kg}^{-1}$. About $83.8 \%$ of rice fields with a PUF above 1 were distributed in sites with soil $\mathrm{Mn}_{\mathrm{ox}}$ below $82 \mathrm{mg} \mathrm{kg}^{-1}$. The PUF level in this low- $\mathrm{Mn}_{\mathrm{ox}}$ group averaged 2.0, significantly higher than in the high- $\mathrm{Mn}_{\text {ox }}$ group (average 1.03). Our investigation also showed that $\mathrm{Cd}$ uptake by rice can be significantly inhibited by soil $\mathrm{Mn}_{\mathrm{ox}}$, indicated by the strong negative correlation between soil $\mathrm{Mn}_{\mathrm{ox}}$ and $\mathrm{Cd}$ accumulation in rice roots $(r=-0.389 * *)$ and rice grain $(r=$ $-0.499 * *)$. Our field experiments over four rice growing seasons demonstrate that $\mathrm{Mn}$ application is effective in reducing Cd uptake in rice, as the PUF of rice roots and rice grains decreased by $27.2 \%$ and $44.5 \%$, respectively, as shown in Figure $3 b$.

The average and median value of Mn concentration in paddy soils were 248 and $209 \mathrm{mg} \mathrm{kg}^{-1}$, respectively, far below the soil background value $\left(459 \mathrm{mg} \mathrm{kg}^{-1}\right){ }^{39}$ The high temperature (Table S2) and drainage of paddy fields in the mature stage result in aerobic conditions that enhance the soil acidity and $\mathrm{Mn}^{2+}$ oxidation. ${ }^{6,8,15}$ This in turn aggravates the loss of Mn due to drainage in paddy fields, and consequently weakens the effect of $\mathrm{Mn}$ in suppressing $\mathrm{Cd}$ transfer from soil to rice grain.

The average concentration of $\mathrm{Zn}$ in the vegetable and paddy field was 111 and $99.5 \mathrm{mg} \mathrm{kg}^{-1}$, respectively (Table S5), and slightly higher than the soil background value of $94.5 \mathrm{mg}$ $\mathrm{kg}^{-1}$. ${ }^{39}$ The relationship between soil $\mathrm{Zn}$ and vegetable $\mathrm{Cd}$ was poor $(r=0.064)$. However, a negative correlation $(r=$ $-0.399 * *)$ between $\mathrm{Zn}$ and $\mathrm{Cd}$ accumulation in vegetable soils was found in areas that had a $\mathrm{Zn}: \mathrm{Cd}$ ratio around 50:1. In the paddy fields, $\mathrm{Zn}$ had little influence on Cd accumulation ( $r=$ 0.062 ). These areas suffer from strong acidification and serious $\mathrm{Cd}$ contamination, which cause a dysfunction in the soil-crop 

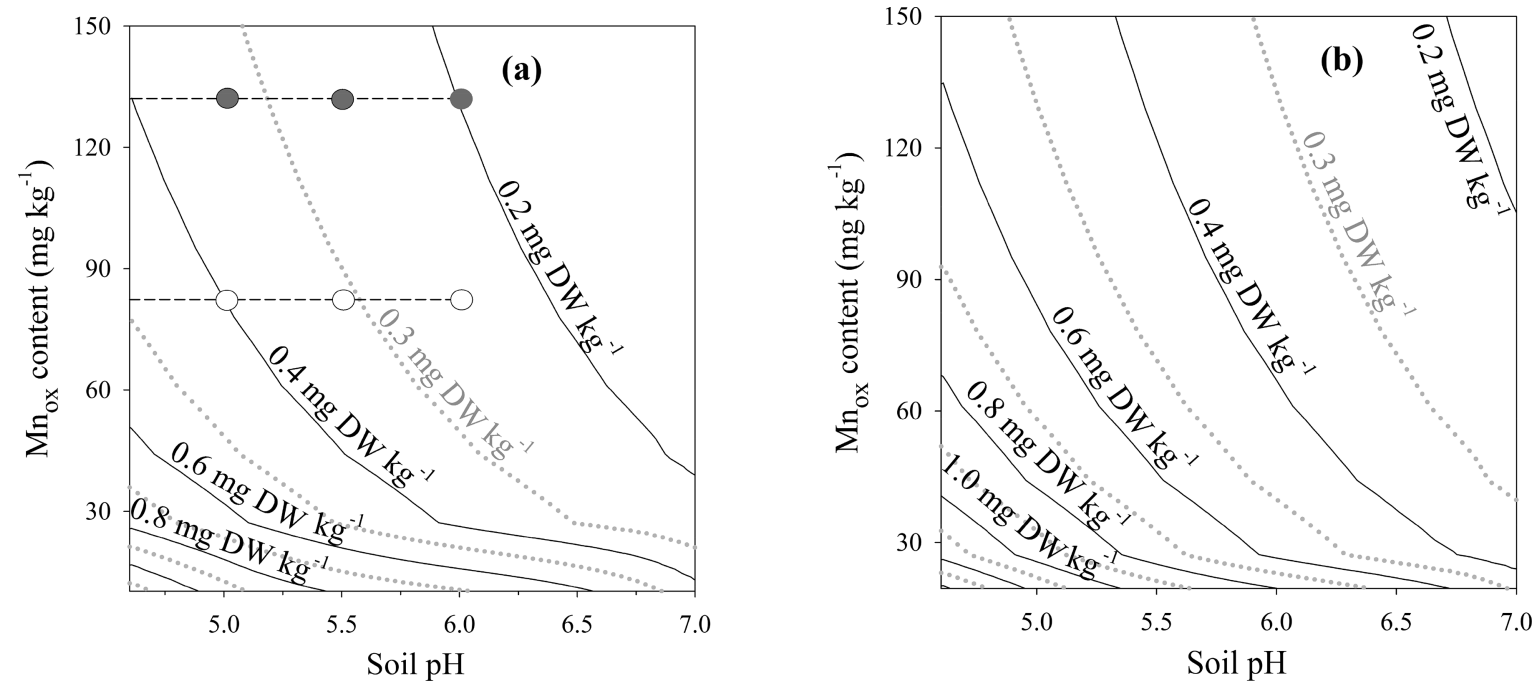

Figure 4. Predicted $\mathrm{Cd}$ concentrations in rice $\left(\mathrm{mg} \mathrm{DW} \mathrm{kg}^{-1}\right)$ grown in a combination of different $\mathrm{pH}$, soil $\mathrm{Mn}_{\mathrm{ox}}$, and soil $\mathrm{Cd}$ of (a) low contamination $\left(0.3 \mathrm{mg} \mathrm{kg}^{-1}\right)$ and $(\mathrm{b})$ heavy contamination $\left(1.5 \mathrm{mg} \mathrm{kg}^{-1}\right)$. The white and grey circles from left to right indicate the predicted Cd concentration in rice harvested from low $\mathrm{Mn}_{\mathrm{ox}}\left(82 \mathrm{mg} \mathrm{kg}^{-1}\right)$ and high $\mathrm{Mn}_{\mathrm{ox}}\left(132 \mathrm{mg} \mathrm{kg}^{-1}\right)$ soil with $\mathrm{pH}$ of 5.0, 5.5, and 6.0, respectively.

ecosystem and alter the normal ratios of $\mathrm{Zn}: \mathrm{Cd}(100: 1$, suggested by Chaney ${ }^{30}$ ).

Risk Prediction. The daily intakes (DI) of $\mathrm{Cd}$ through consumption of vegetables and rice are estimated using the health risk equation and Monte Carlo simulation (details are given in the SI). DI averaged 0.06 and $2.1 \mu \mathrm{g} \mathrm{BW} \mathrm{kg}^{-1} \mathrm{day}^{-1}$ for vegetable and rice, respectively (Figure S2). About $85.5 \%$ of the adult population living in affected areas had a daily $\mathrm{Cd}$ intake risk above the toxic value recommended by JECFA $(0.8 \mu \mathrm{g}$ BW $\mathrm{kg}^{-1}$ day $\left.^{-1}\right),{ }^{4}$ with rice consumption contributing $97.2 \%$ of the risk (Figure S2). A ratio of $\mathrm{Cd}$ to $\mathrm{Zn}$ in food crops below 0.015 is reported to effectively protect from $\mathrm{Cd}$-induced health impacts. ${ }^{1,3}$ About $98.3 \%$ and $23.9 \%$ of vegetables and rice samples were within this safe ratio, respectively. Considering the greater risk posed by rice consumption, the factors governing $\mathrm{Cd}$ accumulation in rice are more important than those in vegetables in terms of practical farmland management.

A linear relationship describing $\mathrm{Cd}$ transfer from soil to rice grain was also established using the stepwise multiple linear regression method, as shown in eq 5 in Table 1. On the basis of the Monte Carlo simulation method, the derived transfer function (eq 5) can be used to predict the likely content of $\mathrm{Cd}$ in rice grains in different soil conditions (for the parameters of $\mathrm{pH}$ and $\mathrm{Mn}_{\mathrm{ox}}$ in eq 5, values were randomly drawn from their measured distributions ${ }^{24}$ ). As expected, the estimated $\mathrm{Cd}$ concentration in rice increased with soil $\mathrm{Cd}$ concentrations and decreased with soil $\mathrm{Mn}_{\mathrm{ox}}$ content and soil $\mathrm{pH}$ (Figure 4). Cropping rice in low contamination area (soil Cd $=0.3 \mathrm{mg}$ $\left.\mathrm{kg}^{-1}\right),{ }^{37}$ caused a $94.5 \%$ and $43.3 \%$ likelihood of $\mathrm{Cd}$ to accumulate above the China food standard limit of $0.2 \mathrm{mg} \mathrm{DW}$ $\mathrm{kg}^{-1},{ }^{40}$ and the WHO limit of $0.4 \mathrm{mg} \mathrm{DW} \mathrm{kg}^{-1}$, ${ }^{41}$ respectively; while this risk was significantly increased to $99.4 \%$ and $81.6 \%$, respectively, in seriously contaminated soils ( soil Cd $=1.5 \mathrm{mg}$ $\left.\mathrm{kg}^{-1}\right) .{ }^{37}$

As illustrated in Figure 4a, under uncontaminated soil conditions (soil $\mathrm{Cd}<0.3 \mathrm{mg} \mathrm{kg}{ }^{-1}$ ), ${ }^{37}$ and low levels of $\mathrm{Mn}_{\mathrm{ox}}$ $\left(82 \mathrm{mg} \mathrm{kg}^{-1}\right)$, rice grown in strong acidic soil $(\mathrm{pH}=5.0)$, acidic soil $(\mathrm{pH}=5.5)$, and near-neutral soil $(\mathrm{pH}=6.0)^{37}$ resulted in a risk of $100 \%, 78.7 \%$, and $36.7 \%$, respectively, of producing $\mathrm{Cd}-$ tainted rice $\left(>0.4 \mathrm{mg} \mathrm{DW} \mathrm{kg}^{-1}\right)$. This risk significantly decreased to $82 \%, 39.5 \%$, and $18.8 \%$, respectively, when soil
$\mathrm{Mn}_{\mathrm{ox}}$ increased to $132 \mathrm{mg} \mathrm{kg}{ }^{-1}$ (Figure 4a). This result indicates the influence of $\mathrm{Mn}_{\mathrm{ox}}$ and $\mathrm{pH}$ on $\mathrm{Cd}$ accumulation in rice is interactive and dynamic. $\mathrm{Mn}_{\mathrm{ox}}$ content controlled the variations of rice $\mathrm{Cd}$ when $\mathrm{Mn}_{\mathrm{ox}}$ was less than $82 \mathrm{mg} \mathrm{kg}^{-1}$, especially in $\mathrm{pH}$ below 5.5 .

Field experiments indicate that in improved soil conditions, with a $\mathrm{pH}$ of $\sim 6.0$ and a $\mathrm{Mn}_{\text {ox }}$ of $\sim 132 \mathrm{mg} \mathrm{kg}^{-1}$, the risk of rice Cd exceeding $0.2 \mathrm{mg} \mathrm{DW} \mathrm{kg}{ }^{-1}$ significantly decreased from $100 \%$ to $33.3 \%$ (Figure S3), agreeing with our estimation (Figure 4a). To maintain acceptable Cd concentrations in rice grains $\left(<0.2 \mathrm{mg} \mathrm{DW} \mathrm{kg}{ }^{-1}\right),{ }^{40}$ soil management strategies should aim to improve soil $\mathrm{pH}$ to $\sim 6.0$ and soil $\mathrm{Mn}$ to $\sim 345$ $\mathrm{mg} \mathrm{kg}{ }^{-1}$ (roughly corresponding to $132 \mathrm{mg} \mathrm{kg}^{-1} \mathrm{Mn}_{\mathrm{ox}}$, Figure S4).

At present, the continuous acidification of paddy soils raises concerns in the government and farming communities. ${ }^{11,42}$ To improve the acidic condition of cropland soil, large applications of lime and biochar have been conducted in many areas of southern China., ${ }^{9,42}$ However, the use of these materials may result in a serious loss of soil trace elements, especially in paddy soils with a low level of Mn. Rebuilding the element balance in cropland soils is more likely to provide an effective risk-based approach for safer crop production, rather than enforcing a strict ban on the usage of discharging Cd-contaminated effluents on soils, or removing the $\mathrm{Cd}$ from contaminated soils via engineering projects. Characterizing the $K_{\mathrm{d}}$ and PUF and their relationships with site-specific factors in probabilistic terms provide different tools to assess soil contamination and are useful in effective risk management.

\section{ASSOCIATED CONTENT}

\section{S Supporting Information}

The Supporting Information is available free of charge on the ACS Publications website at DOI: 10.1021/acs.jafc.7b01931.

Details on $\mathrm{Cd}$ intake risk estimation (eqs S1-S3), regional investigation (Tables $\mathrm{S} 1-\mathrm{S} 5$, Figure $\mathrm{S} 1$ ) and the relationship between environmental factors and $K_{\mathrm{d}}$ and PUF from vegetable and paddy fields (Tables S6, Figures S2-S4) (PDF) 


\section{AUTHOR INFORMATION}

\section{Corresponding Author}

*Phone: +86-010-62843981. E-mail: wpchen@rcees.ac.cn (W.P.C.).

\section{ORCID}

Yang Yang: 0000-0003-0232-0481

Notes

The authors declare no competing financial interest.

\section{ACKNOWLEDGMENTS}

Funding for this project was provided by the Special Foundation of State Key Lab of Urban and Regional Ecology (SKLURE2013-1-04) and National Natural Science Foundation of China (41173123).

\section{REFERENCES}

(1) Reeves, P. G.; Chaney, R. L. Bioavailability as an issue in risk assessment and management of food cadmium: A review. Sci. Total Environ. 2008, 398, 13-19.

(2) Clemens, S.; Aarts, M. G. M.; Thomine, S.; Verbruggen, N. Plant science: the key to preventing slow cadmium poisoning. Trends Plant Sci. 2013, 18, 92-99.

(3) Chaney, R. L. Food safety issues for mineral and organic fertilizers. Adv. Agron. 2012, 117, 51-116.

(4) JECFA (Joint FAO/WHO Expert Committee on Food Additives). Joint FAO/WHO Expert Committee on Food Additives, $73^{\text {rd }}$ meeting; World Health Organization: Geneva, 2010.

(5) Gaw, S. K.; Kim, N. D.; Northcott, G. L.; Wilkins, A. L.; Robinson, G. Uptake of $\Sigma D D T$, arsenic, cadmium, copper, and lead by lettuce and radish grown in contaminated horticultural soils. J. Agric. Food Chem. 2008, 56, 6584-6593.

(6) Honma, T.; Ohba, H.; Kaneko-Kadokura, A.; Makino, T.; Nakamura, K.; Katou, H. Optimal soil Eh, pH, and water management for simultaneously minimizing arsenic and cadmium concentrations in rice grains. Environ. Sci. Technol. 2016, 50, 4178-4185.

(7) Ishikawa, S.; Ishimaru, Y.; Igura, M.; Kuramata, M.; Abe, T.; Senoura, T.; Hase, Y.; Arao, T.; Nishizawa, N. K.; Nakanishi, H. Ionbeam irradiation, gene identification, and marker-assisted breeding in the development of low-cadmium rice. Proc. Natl. Acad. Sci. U. S. A. 2012, 109, 19166-19171.

(8) Fulda, B.; Voegelin, A.; Kretzschmar, R. Redox-controlled changes in cadmium solubility and solid-phase speciation in a paddy soil as affected by reducible sulfate and copper. Environ. Sci. Technol. 2013, 47, 12775-12783.

(9) Hu, Y.; Cheng, H.; Tao, S. The challenges and solutions for cadmium-contaminated rice in China: a critical review. Environ. Int. 2016, 92-93, 515-532.

(10) Wu, L.; Tang, S.; He, D.; Wu, X.; Shaaban, M.; Wang, M.; Zhao, J.; Khan, I.; Zheng, X.; Hu, R.; Horwath, W. R. Conversion from rice to vegetable production increases $\mathrm{N}_{2} \mathrm{O}$ emission via increased soil organic matter mineralization. Sci. Total Environ. 2017, 583, 190-201.

(11) Zhao, F. J.; Ma, Y.; Zhu, Y. G.; Tang, Z.; McGrath, S. P. Soil contamination in China: current status and mitigation strategies. Environ. Sci. Technol. 2015, 49, 750-759.

(12) McBride, M. B.; Shayler, H. A.; Spliethoff, H. M.; Mitchell, R. G.; Marquez-Bravo, L. G.; Ferenz, G. S.; Russell-Anelli, J. M.; Casey, L.; Bachman, S. Concentrations of lead, cadmium and barium in urban garden-grown vegetables: The impact of soil variables. Environ. Pollut. 2014, 194, 254-261.

(13) Wang, M.; Chen, W.; Peng, C. Risk assessment of Cd polluted paddy soils in the industrial and township areas in Hunan, Southern China. Chemosphere 2016, 144, 346-351.

(14) Bonten, L. T.; Groenenberg, J. E.; Weng, L.; Van Riemsdijk, W. $\mathrm{H}$. Use of speciation and complexation models to estimate heavy metal sorption in soils. Geoderma 2008, 146, 303-310.
(15) Römkens, P.; Guo, H. Y.; Chu, C. L.; Liu, T. S.; Chiang, C. F.; Koopmans, G. Characterization of soil heavy metal pools in paddy fields in Taiwan: chemical extraction and solid-solution partitioning. J. Soils Sediments 2009, 9, 216-228.

(16) de Vries, W.; McLaughlin, M. J.; Groenenberg, J. E. Transfer functions for solid-solution partitioning of cadmium for Australian soils. Environ. Pollut. 2011, 159, 3583-3594.

(17) Groenenberg, J. E.; Dijkstra, J. J.; Bonten, L. T. C.; de Vries, W.; Comans, R. N. J. Evaluation of the performance and limitations of empirical partition-relations and process based multisurface models to predict trace element solubility in soils. Environ. Pollut. 2012, 166, $98-$ 107.

(18) Lim, G. H.; Seo, B. H.; Kim, K. H.; Kim, H. S.; Kim, W. I.; Owens, G.; Kim, K. R. Transfer functions for estimating phytoavailable $\mathrm{Cd}$ and $\mathrm{Pb}$ in metal contaminated paddy and upland soils: Implications for phytoavailability based land management. Geoderma 2016, 270, 89-97.

(19) Samsøe-Petersen, L.; Larsen, E. H.; Larsen, P. B.; Bruun, P. Uptake of trace elements and PAHs by fruit and vegetables from contaminated soils. Environ. Sci. Technol. 2002, 36, 3057-3063.

(20) Rodrigues, S. M.; Henriques, B.; da Silva, E. F.; Pereira, M. E.; Duarte, A. C.; Groenenberg, J. E.; Römkens, P. F. A. M. Evaluation of an approach for the characterization of reactive and available pools of 20 potentially toxic elements in soils: Part II-Solid-solution partition relationships and ion activity in soil solutions. Chemosphere 2010, 81, $1560-1570$

(21) Chen, W.; Li, L.; Chang, A. C.; Wu, L.; Chaney, R. L.; Smith, R.; Ajwa, H. Characterizing the solid-solution partitioning coefficient and plant uptake factor of $\mathrm{As}, \mathrm{Cd}$, and $\mathrm{Pb}$ in California croplands. Agric., Ecosyst. Environ. 2009, 129, 212-220.

(22) Luo, X. S.; Zhou, D. M.; Liu, X. H.; Wang, Y. J. Solid/solution partitioning and speciation of heavy metals in the contaminated agricultural soils around a copper mine in eastern Nanjing city, China. J. Hazard. Mater. 2006, 131, 19-27.

(23) Ding, C.; Zhang, T.; Wang, X.; Zhou, F.; Yang, Y.; Huang, G. Prediction model for cadmium transfer from soil to carrot (Daucus carota L.) and its application to derive soil thresholds for food safety. J. Agric. Food Chem. 2013, 61, 10273-10282.

(24) Augustsson, A. L. M.; Uddh-Söderberg, T. E.; Hogmalm, K. J.; Filipsson, M. E. M. Metal uptake by homegrown vegetables-The relative importance in human health risk assessments at contaminated sites. Environ. Res. 2015, 138, 181-190.

(25) Le, T. T. Y.; Hendriks, A. J. Uncertainties associated with lacking data for predictions of solid-solution partitioning of metals in soil. Sci. Total Environ. 2014, 490, 44-49.

(26) Swartjes, F. A.; Versluijs, K. W.; Otte, P. F. A tiered approach for the human health risk assessment for consumption of vegetables from with cadmium-contaminated land in urban areas. Environ. Res. 2013, 126, 223-231.

(27) Peng, C.; Wang, M.; Chen, W. Modelling cadmium contamination in paddy soils under long-term remediation measures: Model development and stochastic simulations. Environ. Pollut. 2016, 216, 146-155.

(28) Sauvé, S.; Hendershot, W.; Allen, H. E. Solid-solution partitioning of metals in contaminated soils: dependence on $\mathrm{pH}$ total metal burden, and organic matter. Environ. Sci. Technol. 2000, 34, $1125-1131$

(29) Groenenberg, J. E.; Römkens, P. F. A. M.; Comans, R. N. J.; Luster, J.; Pampura, T.; Shotbolt, L.; Tipping, E.; De Vries, W. Transfer functions for solid-solution partitioning of cadmium, copper, nickel, lead and zinc in soils: derivation of relationships for free metal ion activities and validation with independent data. Eur. J. Soil Sci. 2010, 61, 58-73.

(30) Chaney, R. L. How does contamination of rice soils with Cd and $\mathrm{Zn}$ cause high incidence of human $\mathrm{Cd}$ disease in subsistence rice farmers. Curr. Pollut. Rep. 2015, 1, 13-22.

(31) Wang, H.; Guan, D.; Zhang, R.; Chen, Y.; Hu, Y.; Xiao, L. Soil aggregates and organic carbon affected by the land use change from rice paddy to vegetable field. Ecol. Eng. 2014, 70, 206-211. 
(32) Yang, Y.; Chen, W.; Wang, M.; Peng, C. Regional accumulation characteristics of cadmium in vegetables: Influencing factors, transfer model and indication of soil threshold content. Environ. Pollut. 2016, 219, 1036-1043.

(33) Lu, R. K. Analytical Methods of Agricultural Chemistry in Soil; China Agricultural Science and Technology Press: Beijing, China (in Chinese), 2000.

(34) Guo, W.; Zhang, P.; Jin, L.; Hu, S. Rice cadmium monitoring using heat-extraction electrothermal atomic absorption spectrometry. J. Anal. At. Spectrom. 2014, 29, 1949-1954.

(35) Du, C.; Luo, L.; Guo, W.; Jin, L.; Chen, B.; Hu, S. Accurate determination of trace cadmium in geological reference materials by closed vessel acid digestion ETAAS. Atom. Spectrosc. 2015, 36, 141145.

(36) Zhang, H.; Luo, Y.; Song, J.; Zhang, H.; Xia, J.; Zhao, Q. Predicting $\mathrm{As}, \mathrm{Cd}$ and $\mathrm{Pb}$ uptake by rice and vegetables using field data from China. J. Environ. Sci. 2011, 23, 70-78.

(37) SEPAC (State Environmental Protection Administration of China). Chinese environmental quality standard for soils (GB156181995) (in Chinese), 1995.

(38) Sun, B.; Dong, Z. X.; Zhang, X. X.; Li, Y.; Cao, H.; Cui, Z. L. Rice to vegetables: short- versus long-term impact of land-use change on the indigenous soil microbial community. Microb. Ecol. 2011, 62, 474-485.

(39) SEPAC (State Environmental Protection Administration of China). Total Station of China Environment Monitoring, Chinese Soil Element Background Values; China Environment Science Press: Beijing (in Chinese), 1990.

(40) SHAC (State Health Administration of China). Guidelines for limit values of pollutant contents in foods (GB2762-2005) (in Chinese), 2005.

(41) CAC (Codex Alimentarius Commission). Report of the $29^{\text {th }}$ Session of the Codex Alimentarius Commission (ALINORM 06/29/ 41); Codex Alimentarius Commission: Rome, 2006.

(42) Zhu, H.; Chen, C.; Xu, C.; Zhu, Q.; Huang, D. Effects of soil acidification and liming on the phytoavailability of cadmium in paddy soils of central subtropical China. Environ. Pollut. 2016, 219, 99-106. 